\title{
Ambient aerosol concentrations of sugars and sugar-alcohols at four different sites in Norway
}

\author{
K. E. Yttri ${ }^{1}$, C. Dye ${ }^{1}$, and G. Kiss ${ }^{2}$ \\ ${ }^{1}$ Norwegian Institute for Air Research, P.O. Box 100, 2027 Kjeller, Norway \\ ${ }^{2}$ Air Chemistry Group of the Hungarian Academy of Sciences, University of Veszprém, P.O. Box 158, 8201 Veszprém, \\ Hungary
}

Received: 29 March 2007 - Published in Atmos. Chem. Phys. Discuss.: 27 April 2007

Revised: 17 August 2007 - Accepted: 17 August 2007 - Published: 20 August 2007

\begin{abstract}
Sugars and sugar-alcohols are demonstrated to be important constituents of the ambient aerosol water-soluble organic carbon fraction, and to be tracers for primary biological aerosol particles (PBAP). In the present study, levels of four sugars (fructose, glucose, sucrose, trehalose) and three sugar-alcohols (arabitol, inositol, mannitol) in ambient aerosols have been quantified using a novel HPLC/HRMSTOF (High Performance Liquid Chromatography in combination with High Resolution Mass Spectrometry - Time of Flight) method to assess the contribution of PBAP to $\mathrm{PM}_{10}$ and $\mathrm{PM}_{2.5}$. Samples were collected at four sites in Norway at different times of the year in order to reflect the various contributing sources and the spatial and seasonal variation of the selected compounds.

Sugars and sugar-alcohols were present at all sites investigated, underlining the ubiquity of these highly polar organic compounds. The highest concentrations were reported for sucrose, reaching a maximum concentration of $320 \mathrm{ng} \mathrm{m}^{-3}$ in $\mathrm{PM}_{10}$ and $55 \mathrm{ng} \mathrm{m}^{-3}$ in $\mathrm{PM}_{2.5}$. The mean concentration of sucrose was up to 10 times higher than fructose, glucose and the dimeric sugar trehalose. The mean concentrations of the sugar-alcohols were typically lower, or equal, to that of the monomeric sugars and trehalose. Peak concentrations of arabitol and mannitol did not exceed $30 \mathrm{ng} \mathrm{m}^{-3}$ in $\mathrm{PM}_{10}$, and for $\mathrm{PM}_{2.5}$ all concentrations were below $6 \mathrm{ng} \mathrm{m}^{-3}$.

Sugars and sugar-alcohols were associated primarily with coarse aerosols except during wintertime at the suburban site in Elverum, where a shift towards sub micron aerosols was observed. It is proposed that this shift was due to the intensive use of wood burning for residential heating at this site during winter, confirmed by high concurrent concentrations of levoglucosan. Elevated concentrations of sugars in $\mathrm{PM}_{2.5}$ were observed during spring and early summer at the rural background site Birkenes. It is hypothesized that this was due to ruptured pollen.
\end{abstract}

Correspondence to: K. E. Yttri

(key@nilu.no)

\section{Introduction}

The organic carbon (OC) fraction of ambient aerosols is commonly fractionated according to its solubility in water. The water-soluble organic carbon fraction (WSOC) may account for 11-95\% of the OC content in ambient aerosols (Mader et al., 2004). The WSOC fraction has been the issue of several scientific studies during the last years due to its important, but still not well-defined, contribution to $\mathrm{CCN}$-activity (cloud condensation nuclei) of ambient aerosols (Novakov and Penner, 1993; Facchini et al., 1999; Graham et al., 2002; Falkovich et al., 2005; Decesari et al., 2006). However, it also needs to be studied more closely for potential negative health effects (Kamens et al., 1985; Taylor et al., 2002; Tesfaigzi et al., 2002). In addition, an increased knowledge on the molecular level will benefit source attribution and improve the mass balance.

The presence of dicarboxylic acids in ambient aerosols have been reported in several studies and for a number of different sites, ranging from background areas (Kleefeld et al., 2002) to urban areas (Kerminen, et al., 2000; Kawamura and Yasui, 2005). Recent studies on particulate matter emitted from biomass burning, have revealed the presence of a large number of highly oxygenated compounds, with polyfunctional groups, which are lignin, cellulose, and hemicellulose breakdown products (Nolte et al., 2001; Schauer et al., 2001; Fine et al., 2002; Simoneit, 2002). The presence of these compounds in ambient aerosols support the suggestions put forward by Saxenea and Hildemann (1996) in their theoretical approach to determine which groups of compounds are contributing to the WSOC fraction of ambient aerosols. A number of studies have demonstrated the presence of water-soluble humic-like substances in atmospheric aerosols (Havers et al., 1998; Krivácsy et al., 2001; MayolBracero et al., 2002). This refractory polymeric material has features that resemble the chemical properties of humic and fulvic acids found in soil and fresh waters, and are reported to account for a substantial part of the WSOC fraction (Zappoli

Published by Copernicus Publications on behalf of the European Geosciences Union. 


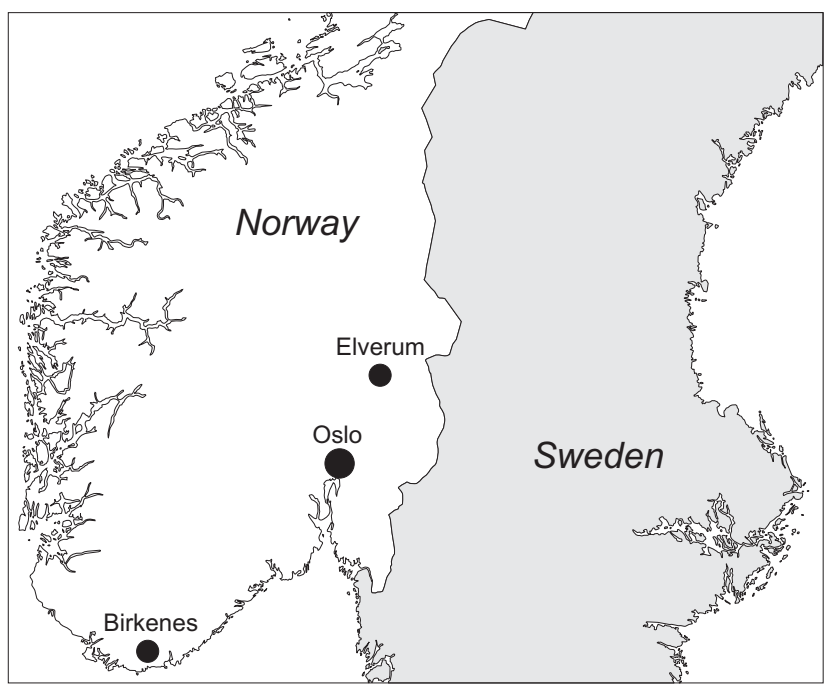

Fig. 1. Map of the southern parts of Norway including the location of the sampling sites Birkenes (rural background), Elverum (suburban), and Oslo (curbside and urban background).

et al., 1999; Mayol-Bracero et al., 2002; Graber and Rudich, 2006). Recently it has been shown that parts of the HULIS are organosulphates (Romero and Oehme, 2005; Surratt et al., 2007)

Based on a solid phase extraction approach (using Oasis HLB columns), Varga et al. (2001) isolated approximately $60 \%$ of the WSOC fraction at a rural site. Most of this isolated organic matter was found to be humic-like substances. According to Kiss et al. (2002), the non-isolated fraction contains even more polar compounds with no fluorescence and absorbing UV light significantly below $240 \mathrm{~nm}$. These findings indicate the lack of polyconjugated structure and UV-absorbing functional groups, such as carbonyl and nitro groups, and supports the presence of polyhydroxy compounds and hydroxy acids. Carbohydrates, which are polyhydroxy compounds, have been the focus in only a few recent studies (e.g. Graham et al., 2002; Pashynska et al., 2002; Carvalho et al., 2003; Graham et al., 2003; Graham et al., 2004; Simoneit et al., 2004; Elbert et al., 2006). Further, it is commonly accepted that there are a significant number of particulate compounds still not identified, and that both biogenic and anthropogenic sources contribute to this pool, either by direct emission or after chemical conversion in the atmosphere. The recent finding and characterization of 2methylthreitol and 2-methylerythritol (Clayes et al., 2004), which were confirmed to be oxidation products of isoprene (Edney et al., 2005; Surratt et al., 2005), supports this. As the WSOC fraction can account for a significant part of ambient aerosols, it is important that its sources are thoroughly investigated. In a recent work on primary biological aerosol particles (PBAP), Graham et al. (2003) make a thorough study in resolving the potential sources of both sugars and sugar-alcohols in fine and coarse ambient aerosols in the Amazon region. They found that sugar-alcohols peak during the night, whereas sugars peak during daytime. These findings were well correlated with increased concentrations of yeasts and other fungal spores present during night, and the specific daytime release of pollen, fern spores and other "giant" bioaerosols. Both sugars and sugar-alcohols were found to be predominantly in the coarse mode. Based on their conclusions, sugars and sugar-alcohols should be good tracers for different types of PBAP, and recently Elbert et al. (2006) estimated a global average emission rate of actively discharged basidiospores $\left(17 \mathrm{Tg}_{\mathrm{g}} \mathrm{year}^{-1}\right)$ on the basis of the sugar-alcohol mannitol. The study of Pashynska et al. (2002) indicates that the same sources may be active in the temperate climate of Europe, based on levels of sugars and sugar-alcohols in Ghent (Belgium). They linked arabitol and mannitol to vegetation and mature leaves in addition to fungi and algae, whereas glucose, fructose, inositol and sucrose were suggested to come from developing leaves, supporting the temporal variation of the relative contribution of sugars and sugar-alcohols to OC seen during their sampling campaign. The study of Pashynska et al. (2002) is so far the only study addressing the contribution of PBAP in an urban environment by investigating temporal variations of sugar and sugar-alcohols. Significantly higher concentrations of sugars and sugar-alcohols were reported for summer than winter in their study.

The purpose of the present study was to quantify the ambient aerosol concentration of sugars and sugar-alcohols in $\mathrm{PM}_{10}$ and $\mathrm{PM}_{2.5}$ in various environments, in order to address the influence of PBAP, their seasonal and spatial variation, and sources. In the few studies reported on sugar and sugaralcohols in ambient aerosols, derivatization and subsequent GC/MS-analysis for quantification has been the method of choice, although with a few exceptions (e.g. Schkolnik et al., 2005). In the present study, levels of sugars and sugaralcohols in 96 ambient aerosol samples have been quantified using a novel HPLC/HRMS-TOF approach where no derivatization is needed prior to the analysis.

\section{Experimental}

\subsection{Site description and measurement period}

Aerosol samples were collected at four sites in Norway (Figure 1): at a curbside site (Helsfyr) and an urban background site (the Sofienberg Park) in Oslo (59 $\left.56^{\prime} \mathrm{N}, 10^{\circ} 44^{\prime} \mathrm{E}\right)$, at a suburban site in Elverum $\left(60^{\circ} 53^{\prime} \mathrm{N}, 11^{\circ} 34^{\prime} \mathrm{E}\right)$, and at a rural background site (Birkenes) $\left(58^{\circ} 23^{\prime} \mathrm{N}, 8^{\circ} 15^{\prime} \mathrm{E}\right)$. The curbside site is located next to one of the most heavily trafficked roads in Oslo (50 000 vehicles pr. $24 \mathrm{~h}$ ). Sampling was performed from 9 September to 3 October 2002. The urban background site is situated in the central parts of Oslo. The site is influenced by various emission sources of particulate 
Table 1. Volumetric flow rate $\left(1 \mathrm{~min}^{-1}\right)$ and filter face velocity $\left(\mathrm{cm} \mathrm{s}^{-1}\right)$ for the aerosol samplers applied.

\begin{tabular}{|c|c|c|c|c|c|}
\hline $\begin{array}{l}\text { Size } \\
\text { fraction }\end{array}$ & $\begin{array}{l}\text { Urban background } \\
\text { Oslo }\end{array}$ & $\begin{array}{l}\text { Curbside } \\
\text { Oslo }\end{array}$ & $\begin{array}{l}\text { Suburban (winter) } \\
\text { Elverum }\end{array}$ & $\begin{array}{l}\text { Suburban (summer) } \\
\text { Elverum }\end{array}$ & $\begin{array}{l}\text { Rural background } \\
\text { Birkenes }\end{array}$ \\
\hline $\mathrm{PM}_{10}$ & $\begin{array}{l}\text { NILU Filter Unit/ } \\
\text { NILU PM } \mathrm{PM}_{10} \text { inlet } \\
\left(101 \mathrm{~min}^{-1}\right) \\
\left(13 \mathrm{~cm} \mathrm{~s}^{-1}\right)\end{array}$ & $\begin{array}{l}\text { NILU Filter Unit/ } \\
\text { NILU PM } \mathrm{PM}_{10} \text { inlet } \\
\left(101 \mathrm{~min}^{-1}\right) \\
\left(13 \mathrm{~cm} \mathrm{~s}^{-1}\right)\end{array}$ & $\begin{array}{l}\text { NILU Filter Unit/ } \\
\text { NILU PM } \mathrm{PM}_{10} \text { inlet } \\
\left(101 \mathrm{~min}^{-1}\right) \\
\left(13 \mathrm{~cm} \mathrm{~s}^{-1}\right)\end{array}$ & $\begin{array}{l}\text { NILU Filter Unit/ } \\
\text { Gent } \mathrm{PM}_{10} \text { inlet } \\
\left(16.71 \mathrm{~min}^{-1}\right) \\
\left(22 \mathrm{~cm} \mathrm{~s}^{-1}\right)\end{array}$ & $\begin{array}{l}\text { Derenda } \mathrm{PM}_{10} \\
\left(381 \mathrm{~min}^{-1}\right) \\
\left(53 \mathrm{~cm} \mathrm{~s}^{-1}\right)\end{array}$ \\
\hline $\mathrm{PM}_{2.5}$ & $\begin{array}{l}\text { NILU-SFU PM } \\
\left(101 \mathrm{~min}^{-1}\right) \\
\left(13 \mathrm{~cm} \mathrm{~s}^{-1}\right)\end{array}$ & $\begin{array}{l}\text { Derenda } \mathrm{PM}_{2.5} \\
\left(381 \mathrm{~min}^{-1}\right) \\
\left(53 \mathrm{~cm} \mathrm{~s}^{-1}\right)\end{array}$ & $\begin{array}{l}\text { NILU-SFU PM } 2.5 \\
\left(101 \mathrm{~min}^{-1}\right) \\
\left(13 \mathrm{~cm} \mathrm{~s}^{-1}\right)\end{array}$ & $\begin{array}{l}\text { Derenda } \mathrm{PM}_{2.5} \\
\left(381 \mathrm{~min}^{-1}\right) \\
\left(53 \mathrm{~cm} \mathrm{~s}^{-1}\right)\end{array}$ & $\begin{array}{l}\text { Derenda } \mathrm{PM}_{2.5} \\
\left(381 \mathrm{~min}^{-1}\right) \\
\left(53 \mathrm{~cm} \mathrm{~s}^{-1}\right)\end{array}$ \\
\hline
\end{tabular}

matter typically present in an urban environment, including emissions from residential wood burning during winter (Yttri et al., 2005). The sampling was performed from 21 November to 14 December in 2001. The suburban site in Elverum is located on the outskirts of a residential area and sampling was conducted both for a winter period (30 January to 15 March 2002) and a summer period (22 May to 28 June 2002). This site is heavily influenced by residential wood burning during winter (Yttri et al., 2005). The rural background site, Birkenes, is located approximately $20 \mathrm{~km}$ from the Skagerak coast in the southern part of Norway, and has been part of NILU's nation-wide sampling net since 1973 and part of the EMEP-program since 1977. The site is frequently influenced by episodes of transboundary air pollution from continental Europe. Sampling was conducted throughout the entire year of 2002.

\subsection{Aerosol sampling}

2.2.1 Aerosol sampling for determination of sugars, sugaralcohols, OC and WSOC

Ambient aerosols were collected on prefired $\left(850{ }^{\circ} \mathrm{C}, 3.5 \mathrm{~h}\right)$ quartz fibre filters (Whatman, QM-A, $47 \mathrm{~mm}$ ). Tandem filter set-ups (McDow and Huntzicker, 1990) were applied at all sites, except Birkenes, to correct for the positive artefact introduced by OC during sampling. The QBT approach (quartz fibre filter behind Teflon filter) was applied for both $\mathrm{PM}_{10}$ and $\mathrm{PM}_{2.5}$, except at the urban background site where the QBQ (quartz fibre filter behind quartz fibre filter) approach was applied for $\mathrm{PM}_{10}$. All quartz fibre filters were from the same batch number in order to minimize differences in adsorptive capacity (Kirchstetter et al., 2001). A difference in adsorptive capacity might lead to an erroneous estimate of the particulate OC when using a tandem filter set up. After sampling, the filters were transported back to the laboratory in a mobile freezer $\left(-5^{\circ} \mathrm{C}\right)$, and stored in sealed Petri dishes at $-18^{\circ} \mathrm{C}$ to prevent post-collection evaporation.

Three different samplers were used to collect $\mathrm{PM}_{10}$. At the curbside and urban background site, and during the winter campaign at the suburban site, a NILU filter unit with a NILU
$\mathrm{PM}_{10}$ pre-impactor inlet was used. For the summer campaign at the suburban site, a NILU filter unit with a Gent PM $_{10}$ inlet was used. At the rural background site, a low volume sampler from Derenda was used.

Two different samplers were used to collect $\mathrm{PM}_{2.5}$. At the curbside site, the suburban site (summer campaign) and the rural background site, low volume samplers from Derenda were used, whereas a NILU stacked-filter unit (SFU) with a NILU PM 10 pre-impactor inlet was used at the urban background site and at the suburban site during the winter campaign. At a flow rate of $101 \mathrm{~min}^{-1}$, the NILU-SFU acts as a dichotomous sampler, as the flow through the initial filter ( $8 \mu \mathrm{m}$ pore, $47 \mathrm{~mm}$ Nucleopore) will result in the collection of particles with an equivalent aerodynamic diameter of $\sim 2.5 \mu \mathrm{m}$ on the second filter ( $2 \mu \mathrm{m}$ pore, $47 \mathrm{~mm}$ Zefluor Teflon, Gelman P5PJ047) (Hopke et al., 1997). Sampling was performed on weekdays only $(23 \mathrm{~h})$, except at the rural background site where samples were collected over a period of six days (144 h) each week. The aerosol samplers used at the various sites are listed in Table 1.

\subsubsection{Size distribution measurements of sugars and sugar- alcohols}

At the suburban site, size segregated samples of ambient aerosols were obtained using a Berner low-pressure impactor collecting aerosols on prefired $\left(850^{\circ} \mathrm{C}, 3.5 \mathrm{~h}\right)$ quartz fibre filters $(d=70 \mathrm{~mm}$, cut from 8 " $\times 10$ " Whatman QM-A). The $50 \%$ cut-off diameters of the eight impaction stages were respectively $16 \mu \mathrm{m}, 8.0 \mu \mathrm{m}, 4.0 \mu \mathrm{m}, 2.0 \mu \mathrm{m}, 1.0 \mu \mathrm{m}, 0.5 \mu \mathrm{m}$, $0.250 \mu \mathrm{m}, 0.125 \mu \mathrm{m}$ and $0.060 \mu \mathrm{m}$ at a nominal flow rate of $281 \mathrm{~min}^{-1}$. The sampling time was $47 \mathrm{~h}$.

It should be noted that obtaining size distributions of sugars and sugar-alcohols using quartz fibre filters may have some drawbacks, as they are somewhat thicker than polycarbonate, reducing the jet to plate distance. Along with the rough surface of the quartz fiber filters, this may influence the $50 \%$ cut-off size of the impactor stages, leading to an increased collection efficiency of fine aerosols on impaction stages meant for collection of coarser aerosols. This will in 
turn lead to a mass size distribution that is shifted towards larger diameters for sugars and sugar-alcohols.

\subsection{Thermal-optical transmission analysis}

OC and WSOC were quantified using the thermal-optical transmittance (TOT) instrument from Sunset laboratories Inc., which discriminates between elemental carbon (EC) and $\mathrm{OC}$ and that corrects for charring during analysis. The WSOC fraction was quantified indirectly (Eq. 1) by means of the remaining OC (WINSOC) left on the $1.5 \mathrm{~cm}^{2}$ filter punch after extracting with Milli-Q water $(100 \mathrm{ml})$. It cannot be excluded that also some constituents that are not water-soluble could have been removed during WSOC extraction.

WSOC $=$ OC - WINSOC

In the first mode of the temperature program applied for analysis, the temperature is raised in four steps terminating at $850^{\circ} \mathrm{C}$ (Step 1: $220^{\circ} \mathrm{C}$ for $60 \mathrm{~s}$, step 2: $360^{\circ} \mathrm{C}$ for $60 \mathrm{~s}$, step 3: $525^{\circ} \mathrm{C}$ for $60 \mathrm{~s}$ and step 4: $850^{\circ} \mathrm{C}$ for $90 \mathrm{~s}$ ). During the second mode, the temperature is lowered to $550^{\circ} \mathrm{C}$ before it is raised to $890^{\circ} \mathrm{C}$ in seven steps (Step 1: $550^{\circ} \mathrm{C}$ for $30 \mathrm{~s}$, step 2: $650^{\circ} \mathrm{C}$ for $30 \mathrm{~s}$, step 3: $720^{\circ} \mathrm{C}$ for $30 \mathrm{~s}$, step $4: 790^{\circ} \mathrm{C}$ for $40 \mathrm{~s}$, step 5: $820^{\circ} \mathrm{C}$ for $30 \mathrm{~s}$, step 6: $860^{\circ} \mathrm{C}$ for $20 \mathrm{~s}$ and step 7: $890^{\circ} \mathrm{C}$ for $40 \mathrm{~s}$ ).

2.4 Sample preparation and HPLC/HRMS-TOF analysis of sugars, sugar-alcohols, and monosaccharide anhydrides

Prior to HPLC/HRMS-TOF analysis, punches $\left(1.5-4.0 \mathrm{~cm}^{2}\right)$ of each filter were soaked in Milli-Q water $(1.5 \mathrm{ml})$ and subjected to ultrasonic agitation $(30 \mathrm{~min})$. For the Berner impactor samples, half of each impaction plate was subjected to analysis and the extraction volume was increased to $3 \mathrm{ml}$. Each filter was extracted twice. The extracted volumes were pooled, filtered through a syringe filter $(0.45 \mu \mathrm{m})$ to remove particulates and filter debris, and evaporated to dryness under an $\mathrm{N}_{2}$ atmosphere. The dry extract was redissolved in Milli-Q water $(100 \mu \mathrm{l})$ and isopropanol $(300 \mu \mathrm{l})$ and transferred into an injection vial. Internal standard $\left({ }^{13} \mathrm{C}\right.$-glucose solution, $10 \mu \mathrm{l}, \mathrm{c}=30 \mathrm{mg} \mathrm{l}^{-1}$ ) was added to the filter punches before the sample preparation.

The sum of the $\mathrm{D}$ and $\mathrm{L}$ and $\alpha$ and $\beta$ isomers of the sugars fructose $\left(\mathrm{C}_{6} \mathrm{H}_{12} \mathrm{O}_{6}\right)$, glucose $\left(\mathrm{C}_{6} \mathrm{H}_{12} \mathrm{O}_{6}\right)$, ribose $\left(\mathrm{C}_{5} \mathrm{H}_{10} \mathrm{O}_{5}\right)$, sucrose $\left(\mathrm{C}_{12} \mathrm{H}_{22} \mathrm{O}_{11}\right)$, and trehalose $\left(\mathrm{C}_{12} \mathrm{H}_{22} \mathrm{O}_{11}\right)$, and the sugar-alcohols arabitol $\left(\mathrm{C}_{5} \mathrm{H}_{12} \mathrm{O}_{5}\right)$, erythritol $\left(\mathrm{C}_{4} \mathrm{H}_{10} \mathrm{O}_{4}\right)$, inositol $\left(\mathrm{C}_{6} \mathrm{H}_{12} \mathrm{O}_{6}\right)$ and mannitol $\left(\mathrm{C}_{6} \mathrm{H}_{14} \mathrm{O}_{6}\right)$ were determined using HPLC (Agilent model 1100) combined with HRMSTOF (Micromass model LCT) operated in the negative electrospray mode. The compounds were identified by comparison of retention time obtained by separation on an amino column (Asahipak $\mathrm{NH}_{2}-2 \mathrm{D}, 2.0 \mathrm{~mm}$ id $\times 150 \mathrm{~mm}$ ) with outstanding separation performance of sugars and sugaralcohols. In addition, the mass spectra obtained with authentic standards were compared with real sample analytes.
The limit of quantification (LOQ) at a signal to noise ratio of ten is approximately $30 \mathrm{pg}$ for the individual sugars and sugar-alcohols. To improve the detection limit, $\mathrm{CHCl}_{3}$ was added post column by a T-piece in order to generate gaseous chlorine in the ion source. This procedure generates adducts between the target compounds and chlorine $[\mathrm{M}+\mathrm{Cl}]^{-}$with a superior ionisation repeatability; e.g. sucrose was monitored by the ion $m / z 377$, and $m / z 379\left({ }^{37} \mathrm{Cl}\right.$ isotopic ion) was used as a qualifier. The procedure was used for the samples and the authentic standards as an integrated part of the HPLC/HRMS-TOF quantification method. The target compounds were quantified by the internal standard method. The procedure of the analytical method will be described in a forthcoming paper.

Sample preparation and HPLC/HRMS-TOF analysis of monosaccharide anhydrides were performed according to Dye and Yttri (2005). The methodology holds the combined merits of short preparation, high sensitivity and complete separation of levoglucosan from its isomeric compounds, as evaluated by Schkolnik and Rudich (2006). The methodology has successfully been applied on filter samples containing levoglucosan concentrations ranging from background (Stohl et al., 2007) to urban (Yttri et al., 2005) levels, and adds to the growing number of publications (e.g. Scholknik et al., 2005) using methodology complementary to GC/MS for quantification of monosaccharide anhydrides.

\section{Results and discussion}

3.1 Concentrations of sugars and sugar-alcohols in ambient aerosols

Using a novel HPLC/HRMS-TOF method, five sugars (fructose, glucose, ribose, sucrose and trehalose) and four sugaralcohols (arabitol, erythritol, inositol and mannitol) were quantified in 96 aerosol filter samples. Their concentrations in $\mathrm{PM}_{10}$ and $\mathrm{PM}_{2.5}$ are reported in Table 2 and Table 3, respectively, except ribose and erythritol, which occurred only randomly and at very low concentrations.

The presence of sugars and sugar-alcohols in ambient aerosols were demonstrated at all sites investigated, underlining the ubiquity of these highly polar organic compounds. Sucrose was the most abundant sugar in both $\mathrm{PM}_{10}$ and $\mathrm{PM}_{2.5}$, except at the rural background site, reaching a maximum concentration of $320 \mathrm{ng} \mathrm{m}^{-3}$ in $\mathrm{PM}_{10}$ and $55 \mathrm{ng} \mathrm{m}^{-3}$ in $\mathrm{PM}_{2.5}$. The mean concentrations of sucrose were up to 10 times higher than that of fructose, glucose and trehalose, exceeding $100 \mathrm{ng} \mathrm{m}^{-3}$ in $\mathrm{PM}_{10}$ at the urban background site, and at the suburban site during the summer campaign. The mean concentrations of the sugar-alcohols were typically lower or equal to that of the monomeric sugars and trehalose. Maximum concentrations of sugar-alcohols did not exceed $30 \mathrm{ng} \mathrm{m}^{-3}$ in $\mathrm{PM}_{10}$, and for $\mathrm{PM}_{2.5}$ all concentrations were below $6 \mathrm{ng} \mathrm{m}^{-3}$. 
Table 2. Mean (min-max) concentrations of sugars and sugar-alcohols in $\mathrm{PM}_{10}\left(\mathrm{ng} \mathrm{m}^{-3}\right)$.

\begin{tabular}{llllllll}
\hline & \multicolumn{3}{c}{ Sugars } & \multicolumn{3}{c}{ Sugar-alcohols } \\
\hline Site & Fructose & Glucose & Sucrose & Trehalose & Arabitol & Inositol & Mannitol \\
\hline Urb. background & 42 & 47 & 150 & 29 & 5.3 & 2.7 & 8.1 \\
(Fall) $(\mathrm{n}=8)$ & $(4.6-90)$ & $(8.4-93)$ & $(17-320)$ & $($ n.d.-65) & $(2.0-11)$ & $($ n.d.-9.3) & $(1.1-19)$ \\
Curbside & 20 & 31 & 71 & 27 & 18 & 2.1 & 20 \\
$($ Fall) $(\mathrm{n}=5)$ & $(8.8-37)$ & $(13-54)$ & $(25-130)$ & $(11-45)$ & $(7.8-24)$ & $($ n.d.-2.8) & $(9.0-30)$ \\
Suburban & 11 & 22 & 95 & 13 & 5.3 & 3.4 & 4.2 \\
(Winter) $(\mathrm{n}=5)$ & $(3.4-21)$ & $(5.4-32)$ & $(6.0-160)$ & $(2.3-18)$ & $(1.5-8.4)$ & $(1.5-5.1)$ & $(0.86-14)$ \\
Suburban & 11 & 19 & 110 & 30 & 20 & 2.5 & 18 \\
$($ Summer $)(\mathrm{n}=6)$ & $(3.3-25)$ & $(10-34)$ & $(22-270)$ & $(15-51)$ & $(17-24)$ & $(1.8-3.8)$ & $(12-24)$ \\
Rural & 1.4 & 3.7 & 1.0 & 3.8 & 6.0 & 0.5 & 4.3 \\
$($ Annual $)(\mathrm{n}=22)$ & $(0.30-3.9)$ & $(0.93-7.2)$ & $(0.11-3.5)$ & $(0.76-10)$ & $(0.48-19)$ & $($ n.d.-1.8) & $($ n.d.-10) \\
\hline
\end{tabular}

n.d. = not detected

Table 3. Mean (min-max) concentrations of sugars and sugar-alcohols in $\mathrm{PM}_{2.5}\left(\mathrm{ng} \mathrm{m}^{-3}\right)$.

\begin{tabular}{|c|c|c|c|c|c|c|c|}
\hline \multirow[b]{2}{*}{ Site } & \multicolumn{4}{|c|}{ Sugars } & \multicolumn{3}{|c|}{ Sugar-alcohols } \\
\hline & Fructose & Glucose & Sucrose & Trehalose & Arabitol & Inositol & Mannitol \\
\hline $\begin{array}{l}\text { Urb. background } \\
\text { Fall }(\mathrm{n}=8)\end{array}$ & $\begin{array}{l}3.3 \\
\text { (n.d.-5.1) }\end{array}$ & $\begin{array}{l}7.2 \\
(4.3-12)\end{array}$ & $\begin{array}{l}15 \\
(5.1-32)\end{array}$ & $\begin{array}{l}5.3 \\
\text { (n.d.-11) }\end{array}$ & $\begin{array}{l}1.0 \\
\text { (n.d.-2.6) }\end{array}$ & n.d & $\begin{array}{l}1.6 \\
\text { (n.d.-4.2) }\end{array}$ \\
\hline Curbside & 1.6 & 3.1 & 3.8 & 2.0 & 1.7 & 1.0 & 2.0 \\
\hline$($ Fall $)(n=5)$ & $(0.79-2.1)$ & $(2.1-5.2)$ & $(2.0-5.1)$ & $(0.77-3.5)$ & $(1.0-3.2)$ & $(0.82-1.4)$ & $(0.81-4.3)$ \\
\hline $\begin{array}{l}\text { Suburban } \\
\text { (Winter) }(\mathrm{n}=5)\end{array}$ & $\begin{array}{l}14^{1)} \\
(7.9-22)\end{array}$ & $\begin{array}{l}\left.20^{2}\right) \\
(15-29)\end{array}$ & - & $\begin{array}{l}9.8 \\
(4.8-16)\end{array}$ & $\begin{array}{l}4.3 \\
(1.2-5.9)\end{array}$ & $\begin{array}{l}2.5 \\
(2.0-3.2)\end{array}$ & $\begin{array}{l}2.8 \\
(2.1-4.6)\end{array}$ \\
\hline $\begin{array}{l}\text { Suburban } \\
\text { (Summer) }(n=6)\end{array}$ & $\begin{array}{l}3.3 \\
(2.0-4.5)\end{array}$ & $\begin{array}{l}5.2 \\
(3.6-6.9)\end{array}$ & $\begin{array}{l}24 \\
(4.8-55)\end{array}$ & $\begin{array}{l}4.1 \\
(2.6-5.8)\end{array}$ & $\begin{array}{l}2.0 \\
(1.1-3.0)\end{array}$ & $\begin{array}{l}0.77 \\
(0.59-0.92)\end{array}$ & $\begin{array}{l}2.0 \\
(1.0-2.9)\end{array}$ \\
\hline $\begin{array}{l}\text { Rural background } \\
\text { (Annual) }(n=22)\end{array}$ & $\begin{array}{l}0.57 \\
\text { (n.d.-3.3) }\end{array}$ & $\begin{array}{l}1.2 \\
(0.36-4.4)\end{array}$ & $\begin{array}{l}0.81 \\
(0.16-6.4)\end{array}$ & $\begin{array}{l}0.78 \\
(0.14-3.9)\end{array}$ & $\begin{array}{l}0.42 \\
\text { (n.d.-0.89) }\end{array}$ & $\begin{array}{l}0.20 \\
\text { (n.d.-1.0) }\end{array}$ & $\begin{array}{l}0.27 \\
\text { (n.d.-0.87) }\end{array}$ \\
\hline
\end{tabular}

1. $n=32 . n=4$

Although combustion of cellulose and hemi-cellulose, which are the major constituents of wood, primarily favours monosaccharide anhydride formation (Sanders et al., 2002), monomeric and dimeric sugars are emitted as well (Nolte et al., 2001). Thus, concurrent measurement of monosaccharide anhydrides is important to sort out non-PBAP sources of fine sugars. For the sites investigated, levels of monosaccharide anhydrides varied considerably, ranging from below detection limit to $1240 \mathrm{ng} \mathrm{m}^{-3}$ (Table 4). Levoglucosan was the most abundant of the MAs, typically accounting for 75$80 \%$.

It should be noted that the different sampling time used at the rural site $(144 \mathrm{~h})$ compared to the other sites $(23 \mathrm{~h})$, could bias the results. This could be important when the source contribution is episodic in nature, and if the duration of the emissions is short compared to the sampling times applied. Furthermore, oxidation and subsequent alteration of the compounds trapped on the filter are likely to be increased during prolonged sampling, underestimating the true ambient concentration. However, studies have shown that certain sugars, such as monosaccharide anhydrides, are resistant towards degradation in the atmosphere over a period of at least 10 days (Fraser and Lakshmanan, 2000).

Concentrations of sugars and sugar-alcohols in urban influenced areas have previously been reported for $\mathrm{PM}_{10}$ in Ghent (Belgium) (Pashynska et al., 2002), and for $\mathrm{PM}_{3}$ in San Joaquin Valley (USA) (Nolte et al., 2001). For Ghent, both summer and wintertime concentrations are higher than those reported for the urban-influenced sites in the present study (Table 2), with the exception of sucrose, whereas the wintertime concentrations reported by Nolte et al. (2001) are within the same range. Levels of sugars and sugar-alcohols have been reported only for a few European rural background sites, Hyytiälä (Finland) (Carvalho et al., 2003; Kourtchev et al., 2005), Melpitz (Germany) (Carvalho et al., 2003), and K-puszta (Ion et al., 2005), and the measurements are mainly 
Table 4. Mean (min-max) concentration of monosaccharide anhydrides in $\mathrm{PM}_{10}\left(\mathrm{ng} \mathrm{m}^{-3}\right)$.

\begin{tabular}{|c|c|c|c|c|}
\hline Site & Levoglucosan & Mannosan & Galactosan & SUM MA \\
\hline Urb. background (Fall) $(\mathrm{n}=8)$ & 193 (n.d. -475 ) & 52 (n.d.-155) & 1.7 (n.d.-6.9) & 246 (n.d.-615) \\
\hline Curbside (Fall) $(\mathrm{n}=5)$ & $45(9.4-109)$ & 8.5 (n.d. -21$)$ & 3.5 (n.d. -7.3 ) & $57(11-134)$ \\
\hline Suburban (Winter) $(\mathrm{n}=5)$ & $605(232-971)$ & $167(56-286)$ & $4.0(1.1-6.8)$ & $772(288-1240)$ \\
\hline Suburban (Summer) $(\mathrm{n}=6)$ & 47 (n.d.-151) & 10 (n.d. -42$)$ & 3 (n.d. -7.5$)$ & 60 (n.d.-201) \\
\hline $\begin{array}{l}\text { Rural background } \\
\text { (Annual) }(n=22)\end{array}$ & $7.8(0.3-25)$ & $1.9(0.1-6.9)$ & 0.6 (n.d. -2.3 ) & $10(0.5-35)$ \\
\hline
\end{tabular}

Table 5. Mean relative contribution of sugars and sugar-alcohols in the $\mathrm{PM}_{2.5}$ fraction to the $\mathrm{PM}_{10}$ fraction (\%).

\begin{tabular}{llllllll}
\hline & \multicolumn{4}{c}{ Sugars } & \multicolumn{3}{c}{ Sugar-alcohols } \\
\hline Site & Fructose & Glucose & Sucrose & Trehalose & Arabitol & Inositol & Mannitol \\
\hline Urb. background (Fall) & 8 & 15 & 10 & 18 & 19 & - & 20 \\
Curbside (Fall) & 8 & 10 & 5 & 7 & 10 & 49 & 10 \\
Suburban (Winter) & $92^{1)}$ & $76^{2)}$ & - & 75 & 82 & 75 & 66 \\
$\begin{array}{l}\text { Suburban (Summer) } \\
\text { Rural background }\end{array}$ & 29 & 27 & 23 & 14 & 10 & 31 & 11 \\
\begin{tabular}{l} 
(Annual) \\
\hline
\end{tabular} & 40 & 33 & 85 & 20 & 7.0 & 39 & 6.3 \\
\hline
\end{tabular}

1. $\mathrm{n}=3$

2. $n=4$

based on sampling campaigns conducted during summer. In general, the concentrations reported in these studies are comparable to those reported in the present study, with the exception of the rural background site Birkenes, where the levels of sugars and sugar-alcohols in $\mathrm{PM}_{2.5}$ are considerably lower. Pashynska et al. (2002), Nolte et al. (2001), Carvalho et al. (2003), Kourtchev et al. (2005), and Ion et al. (2005), all reported concurrent measurements of levoglucosan along with the sugars and sugar-alcohols, indicating that combustion of wood could be a source of fine sugars in these studies.

3.2 Sources and size distributions of sugars and sugaralcohols

The results presented in Table 5 show that sugars and sugaralcohols were associated mainly with coarse aerosols. This is in accordance with results reported from the Amazon region on the natural background aerosol (Graham et al., 2003).

Only $5-10 \%$ of the sugars and sugar-alcohols could be attributed to $\mathrm{PM}_{2.5}$ at the curbside site, when not accounting for inositol. We suggest that resuspension of PBAP promoted by turbulence from vehicular traffic could be a possible reason why so much PBAP was found in the coarse fraction at this highly trafficked site. The mean concentration of levoglucosan at the curbside site was $45 \mathrm{ng} \mathrm{m}^{-3}$, which indicates that only a minor part of the fine aerosol content of sug- ars could be attributed to wood burning. 66-92\% of the sugars and the sugar-alcohols were associated with $\mathrm{PM}_{2.5}$ at the suburban site during the winter campaign, whereas the corresponding range for the summer campaign was $10-31 \%$. This suggests that different sources of sugars and sugar-alcohols prevail at various seasons. The high mean concentration of levoglucosan $\left(605 \mathrm{ng} \mathrm{m}^{-3}\right)$ (Table 4$)$ in the samples collected during winter, strongly suggest that residential wood burning is the source of fine sugars, and possibly sugar-alcohols, and not PBAP. The mean concentration of levoglucosan during the summer campaign was only $47 \mathrm{ng} \mathrm{m}^{-3}$. A similar seasonal pattern of levoglucosan has previously been reported by Zdráhal et al. (2002) and Pashynska et al. (2002). The size distributions obtained for sugars and sugar-alcohols at the suburban site, confirm the shift towards smaller particle sizes during winter reported in Table 5. This is exemplified by the size distributions of arabitol (Figs. 2c and d) and glucose (Figs. 2e and f), which show that the majority of the sugars and the sugar-alcohols were associated with aerosols in the size range $0.250-1.0 \mu \mathrm{m}$ during winter, and with aerosols larger than $2 \mu \mathrm{m}$ in summer. We have not found literature positively confirming the presence of sugaralcohols in wood smoke, although Simoneit et al. (2004) suggested that they might be emitted by thermal stripping during wildfires. Whereas Medeiros et al. (2006) only reported elevated concentrations of certain monomeric sugars during wildfires, and not for disaccharides and sugar-alcohols, 

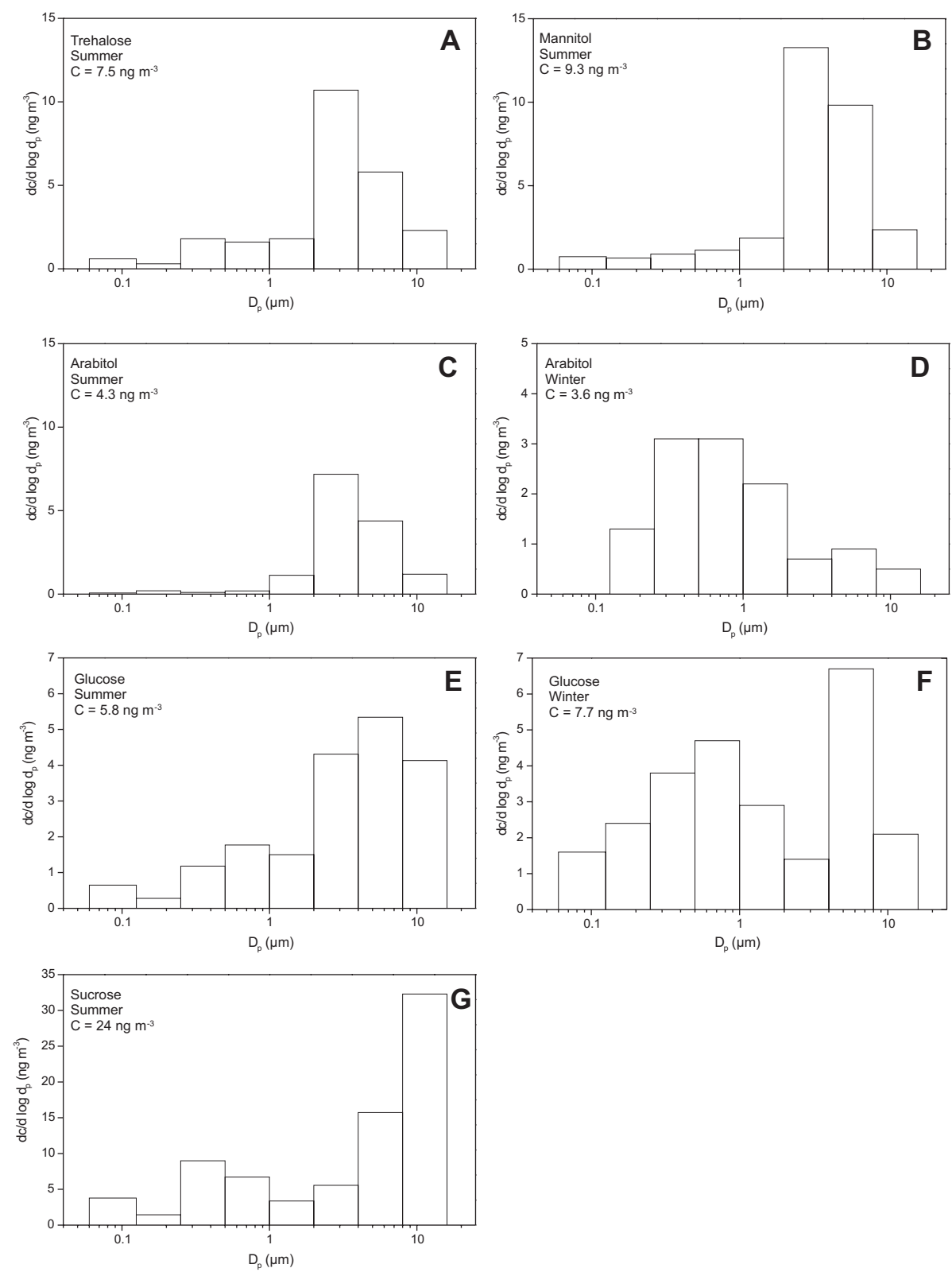

Fig. 2. Size-distributions of trehalose (A), mannitol (B), arabitol $(\mathbf{C}$ and $\mathbf{D})$, glucose $(\mathbf{E}$ and $\mathbf{F})$ and sucrose $(\mathbf{G})$ obtained from samples collected at the suburban site using a Berner impactor. Samples were collected for both a winter and a summer period. The size-distributions representing the winter campaign were collected during the period 11-13 March 2002, whereas the size-distributions representing the summer campaign were collected during the period 5-7 June 2002.

Medeiros and Simoneit (2007) found mannitol to be present in aerosols sampled from air masses influenced by wild fire emissions. It could also be that the high $\mathrm{PM}_{2.5} / \mathrm{PM}_{10}$ ratio for sugars and sugar-alcohols could be attributed to snow on the ground, which effectively reduces resuspension of decaying biogenic material from the ground, contributing to the coarse fraction.

Although sugars and sugar-alcohols were more abundant in fine aerosols during winter, they still made a contribution in summer. This was more profound for the sugars than for the sugar-alcohols. For the sugars fructose, glucose (Fig. 2e), and sucrose (Fig. 2g), a three-modal size distribution was observed, with two of the modes peaking in the fine mode. The peak height of the modes was found to increase with increasing particle size. The low levels of levoglucosan observed in summer compared to winter suggest other sources of sugars and sugar-alcohols in fine aerosols than wood burning, such as viruses, bacteria, algae, spores of lichens, ferns, and fungi (Matthias-Maser, 1998). Here we suggest that fragmented pollen grains, which are known to contain fructose, glucose 


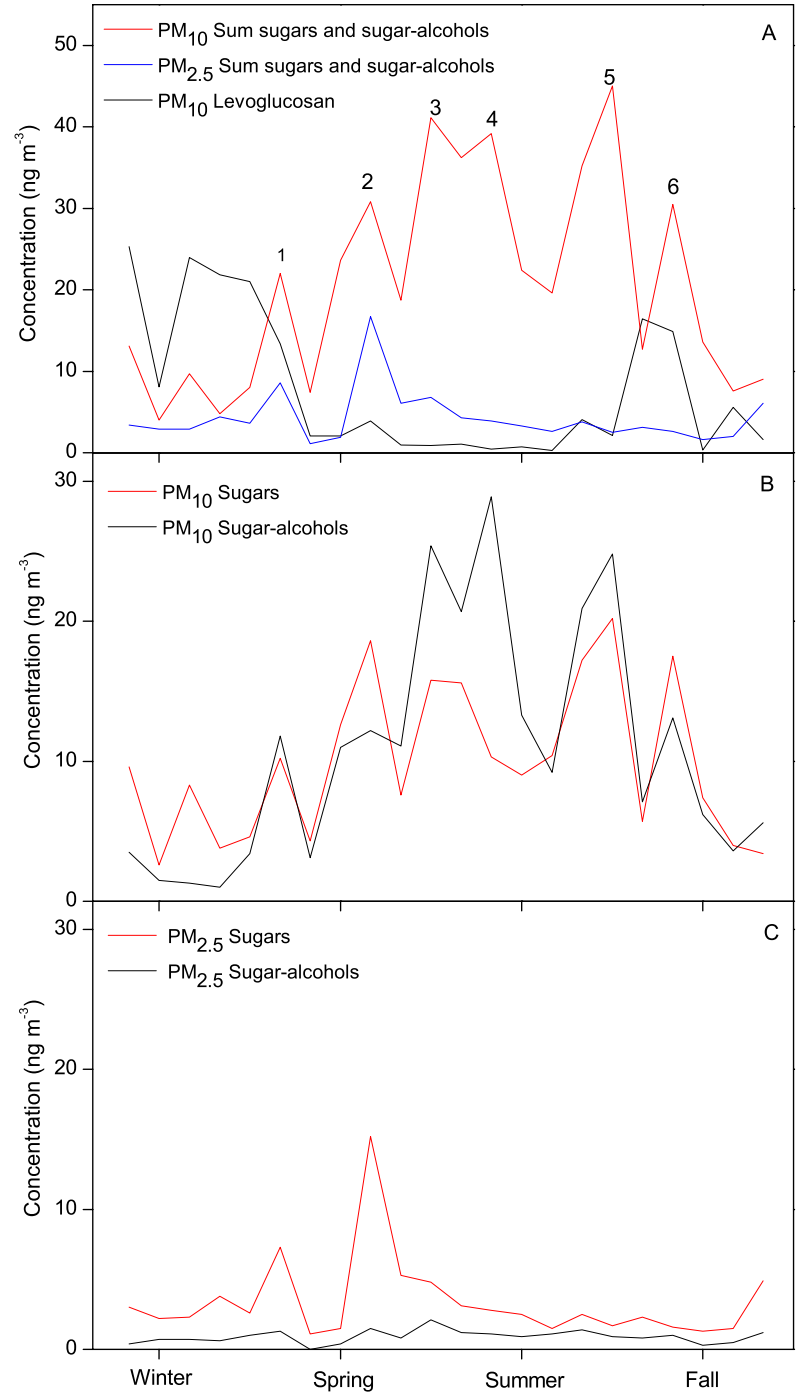

Fig. 3. (A) Annual variation of the sum of sugars (fructose, glucose, sucrose and trehalose) and sugar-alcohols (arabitol, inositol and mannitol) in $\mathrm{PM}_{10}$ and $\mathrm{PM}_{2.5}$ along with concentrations of levoglucosan in $\mathrm{PM}_{10}$ at the rural site Birkenes. (B) Annual variation of sugars and sugar-alcohols in the $\mathrm{PM}_{10}$ fraction at Birkenes. (C) Annual variation of sugars and sugar-alcohols in the $\mathrm{PM}_{2.5}$ fraction at Birkenes.

and sucrose, either in cytoplasmatic vesicles or dissolved in the cytosol (Pacini, 2000), could be a likely source of sugars in the fine aerosol. Taylor et al. (2002) showed that most of the pollen of grass actually remained in the anthers after they had opened, and that following a cycle of wetting and drying, causing the pollen to rupture, followed by wind shedding, respirable aerosols of pollen cytoplasm in the size range $120 \mathrm{~nm}$ to $4.67 \mu \mathrm{m}$ were observed. In a recent study (Taylor et al., 2004), similar results were reported for birch, generating aerosols of pollen cytoplasm in the size range $30 \mathrm{~nm}$ to $4 \mu \mathrm{m}$. Taylor and co-workers (2002) suggested that sim- ilar mechanisms exist for other wind-pollinated trees, weeds and moulds, which indicates that this might be an important source of sugars in fine aerosols. A three modal size distribution have previously been reported for glucose and sucrose for the anthropogenic influenced agricultural site Melpitz (Germany) during spring (Carvalho et al., 2003). In contrast to the finding in the present study, the size distributions of glucose and sucrose at Melpitz were totally dominated by the finest mode, ranging from $0.05-0.390 \mu \mathrm{m}$. Recently, Simoneit et al. (2004) suggested that mono and disaccharides are tracers of soil material and associated microbiota. It can therefore be speculated that agricultural activity, such as ploughing, in nearby areas could be a plausible source as well.

The size distribution of trehalose resembles more closely that of arabitol and mannitol than the other sugars, indicating that it originates from fungal spores (Lewis and Smith, 1967). The common features of the size distributions of these three compounds is a dominant coarse mode, a nearly unimodal size distribution, which peaks within the 2-4 $\mathrm{m}$ size fraction, and an abrupt decrease in the concentration below $2 \mu \mathrm{m}$ (Figs. 2a, b and c). In the study by Bauer et al. (2002), the smallest fungal spores registered had a diameter of $2.0 \mu \mathrm{m}$, underlining their presence in the coarse mode. A somewhat higher concentration of trehalose is observed for the fine mode compared to arabitol and mannitol, indicating some relationship with the other sugars. The size distribution and the concentration of trehalose, arabitol and mannitol are in accordance with that reported for mannitol in Melpitz (Germany) during spring by Carvalho et al. (2003).

Despite that a rather high mean concentration of levoglucosan $\left(193 \mathrm{ng} \mathrm{m}^{-3}\right.$ ) (Table 3) was reported for the urban background site, the $\mathrm{PM}_{2.5} / \mathrm{PM}_{10}$ ratio for the sugars and sugar-alcohols was rather low, ranging from $8-20 \%$. Unlike the suburban site (winter), there was no snow covering the ground during sampling at the urban background site, thus, any coarse sugars and sugar-alcohols resuspended from the ground might have contributed to the low ratios observed.

Although it has been showed that sugars and sugaralcohols are tracers of PBAP, caution should be made when using such highly water-soluble organic compounds as tracers. The great diversity of PBAP, and their various level of decay, could make conversion of sugars and sugar-alcohols into particulate matter uncertain. Fragmented PBAP, which have become depleted of sugars and sugar-alcohols due to rainfall or microorganisms, would not be accounted for by addressing the levels of sugars or sugar-alcohols in aerosol filter samples. Further, studies assessing the solubility of sugars and sugar-alcohols associated with PBAP are needed to address the suitability of these compounds as quantitative tracers of PBAP in various environments. 
3.3 Annual variation of sugars and sugar-alcohols at the rural background site

The sum of the annual mean concentration of the four individual sugars $\left(9.9 \mathrm{ng} \mathrm{m}^{-3}\right)$ and the three individual sugaralcohols $\left(10.8 \mathrm{n} \mathrm{m}^{-3}\right)$ in $\mathrm{PM}_{10}$ at the rural background site, do not differ much (Table 2). However, a higher percentage of the sugars are associated with $\mathrm{PM}_{2.5}$ (34\%) compared to the sugar-alcohols (8.3\%). In general, sugars and sugaralcohols in $\mathrm{PM}_{2.5}$ contribute relatively more to $\mathrm{PM}_{10}$ during winter, spring and early summer (Fig. 3a). In winter, this could be attributed to low levels of sugars and sugaralcohols in the coarse fraction, along with residential wood burning potentially being a dominant source of sugars and sugar-alcohols, as seen from elevated concentrations of levoglucosan (Fig. 3a).

Peak 1 (medio April) and peak 2 (medio June), shown in Figure $3 \mathrm{~A}$, have a relatively high input from the fine fraction, predominantly from sugars (Fig. 3c); $71 \%$ and $82 \%$ of the $\mathrm{PM}_{10}$ sugar content in peak 1 and peak 2 could be accounted for by the fine fraction, whereas the corresponding percentages for the sugar-alcohols were only $11 \%$ and $12 \%$. Notably, peak 1 and peak 2 (Fig. 3a) coincide with the onset of the birch pollen season and the grass pollen season, respectively, and the sugars contributing to these peaks (fructose, glucose and sucrose) are those found in pollen. Pollen from birch and grasses are the two most common types of pollen seen in Norway, and both rely on wind-pollination. Hence, the fine sugar content in Peak 1 and 2 might be attributed to fragmented pollen grains.

The highest concentrations of sugars and sugar-alcohols are observed for the period from June to the beginning of December (Fig. 3a), during which the fine fraction decreases and the coarse fraction increases. This period is characterized by four major peaks (3-6). The elevated concentrations of arabitol, mannitol, and trehalose, and to some extent glucose, associated with these peaks, indicate that the source could be fungal spores (Lewis and Smith, 1967). Late summer and fall is the time of the year when spores from the Cladosporium sp. fungi are at the highest for this part of Norway. The diameter of these spores ranges from 4 to $20 \mu \mathrm{m}$. Matthias-Maser et al. (1998) have previously shown that spores could be the dominating fraction of PBAP, accounting for $40-70 \%$ of the total aerosol number with a radius of $2-5 \mu \mathrm{m}$ in an urban rural-influenced region in December (Mainz, Germany). The maximum concentrations of arabitol and mannitol during late summer and fall coincide with the findings of Pashynska et al. (2002), which reported an increased relative contribution of arabitol and mannitol during late summer.

The narrow gap between $\mathrm{PM}_{10}$ and $\mathrm{PM}_{2.5}$ seen at the end of the year (Fig. 3a) is consistent with snow covering the ground, effectively reducing resuspension of coarse PBAP from the ground to a minimum.
3.4 Relative contribution of sugars and sugar-alcohols to OC and WSOC

\subsection{1 $\mathrm{PM}_{10}$}

The mean carbon content of sugars accounted for $0.4-2.2 \%$ of OC, whereas the corresponding percentage for the sugaralcohols ranged from $<0.1-0.5 \%$ (Table $6 \mathrm{a}$ ). Combined, the carbon content of sugars and sugar-alcohols accounted for $0.5-2.7 \%$ of OC (Table 6a). Notably, the sugars accounted for a significantly higher concentration of $\mathrm{OC}$ at all sites except from the rural site. Correcting for the positive artefact prone to occur during sampling of $\mathrm{OC}$ on quartz fibre filters, the relative contribution of sugars and sugar-alcohols was increased, accounting for $0.6-4.1 \%$ of particulate $\mathrm{OC}\left(\mathrm{OC}_{P}\right)$ (Table 6a). It should be noted that the QBQ approach used at the urban background site, provides a consistently lower estimate of the positive artefact of OC compared to the QBT approach used at the other sites. Thus, the relative contribution of sugars and sugar-alcohols to $\mathrm{OC}_{P}$ at the urban background site are not directly comparable to those sites applying the QBT approach.

In the study by Pashynska et al. (2002), the carbon content of the same sugars as reported in the present study, except trehalose, was found to account for $5.5 \%$ of $\mathrm{OC}$ in $\mathrm{PM}_{10}$ during summer and $1.4 \%$ during winter.

The WSOC concentration was quantified at all but the rural site. The carbon content of the sum of sugars and sugaralcohols was found to account for $0.6-3.9 \%$ of WSOC (Table 6b).

\subsection{2 $\quad \mathrm{PM}_{2.5}$}

The relative contribution of sugars and sugar-alcohols to the fine aerosol OC fraction was considerably lower than for $\mathrm{PM}_{10}$, as they were primarily associated with coarse aerosols (Table 5). The carbon content of sugars accounted for 0.1$0.6 \%$ of OC, whereas the relative contribution of the sugaralcohols did not exceed $0.1 \%$ at any of the sites (Table $7 \mathrm{a}$ ). Between $0.2 \%$ and $0.7 \%$ of the OC could be accounted for by the sum of sugars and sugar-alcohols, whereas it ranged from $0.2 \%$ to $1.0 \%$ when the positive artefact of $\mathrm{OC}$ was accounted for (Table 7a). Care should be taken when comparing the relative contribution of sugars and sugar-alcohols to $\mathrm{PM}_{10}$ and $\mathrm{PM}_{2.5}$ at the urban background site, as the QBQapproach has been used to correct for the positive artefact of $\mathrm{OC}$ for $\mathrm{PM}_{10}$, and the QBT-approach for $\mathrm{PM}_{2.5}$. There is not much difference between the relative contribution of sugars and sugar-alcohols to $\mathrm{OC}$ in $\mathrm{PM}_{2.5}$ and $\mathrm{PM}_{10}$ at the suburban site during winter. This is due to a combination of high concentrations of sugars and sugar-alcohols in the fine fraction (Table 3) and a high $\mathrm{PM}_{2.5} / \mathrm{PM}_{10}$ ratio for OC. The fine aerosol content of WSOC was only quantified for the urban background site, of which the sum of sugars and sugar-alcohols accounted for $0.5 \%$. 
Table 6a. Mean (min-max) relative contribution of the carbon content of sugars and sugar-alcohols to the non-corrected (OC) and the corrected $\left(\mathrm{OC}_{P}\right)$ organic carbon fraction of $\mathrm{PM}_{10}(\%)$.

\begin{tabular}{|c|c|c|c|c|c|c|}
\hline Site & $\begin{array}{l}\text { Sugars/ } \\
\text { OC }\end{array}$ & $\begin{array}{l}\text { Sugars/ } \\
\mathrm{OC}_{P}\end{array}$ & $\begin{array}{l}\text { Sug. alcs./ } \\
\text { OC }\end{array}$ & $\begin{array}{l}\text { Sug. alcs./ } \\
\mathrm{OC}_{P}\end{array}$ & $\begin{array}{l}\text { Sugars and sug. alcs./ } \\
\text { OC }\end{array}$ & $\begin{array}{l}\text { Sugars and sug. } \\
\text { alcs./ } \mathrm{OC}_{P}\end{array}$ \\
\hline $\begin{array}{l}\text { Urb. background } \\
\text { (Fall) }\end{array}$ & $\begin{array}{l}1.0 \\
(0.2-3.8)\end{array}$ & $\begin{array}{l}1.1^{1)} \\
(0.3-4.1)\end{array}$ & $\begin{array}{l}0.1 \\
(<0.1-0.1)\end{array}$ & $\begin{array}{l}0.1^{1)} \\
(<0.1-0.1)\end{array}$ & $\begin{array}{l}1.0 \\
(0.2-3.8)\end{array}$ & $\begin{array}{l}1.1^{1)} \\
(0.3-4.2)\end{array}$ \\
\hline $\begin{array}{l}\text { Curbside } \\
\text { (Fall) }\end{array}$ & $\begin{array}{l}1.0 \\
(0.3-2.4)\end{array}$ & $\begin{array}{l}1.3 \\
(0.4-3.4)\end{array}$ & $\begin{array}{l}0.2 \\
(0.1-0.4)\end{array}$ & $\begin{array}{l}0.3 \\
(0.1-0.6)\end{array}$ & $\begin{array}{l}1.2 \\
(0.5-2.8)\end{array}$ & $\begin{array}{l}1.7 \\
(0.5-4.0)\end{array}$ \\
\hline Suburban & 0.5 & & $<0.1$ & 0.1 & & \\
\hline $\begin{array}{l}\text { (Winter) } \\
\text { Suburban }\end{array}$ & $\begin{array}{l}(0.2-0.8) \\
2.2\end{array}$ & $\begin{array}{l}(0.3-1.1) \\
3.4\end{array}$ & $\begin{array}{l}(<0.1-0.1) \\
0.5\end{array}$ & $\begin{array}{l}(<0.1-0.1) \\
0.8\end{array}$ & $\begin{array}{l}(0.2-0.9) \\
2.7\end{array}$ & $\begin{array}{l}(0.4-1.1) \\
4.1\end{array}$ \\
\hline (Summer) & $(0.8-4.2)$ & $(1.4-6.0)$ & $(0.3-0.8)$ & $(0.5-1.2)$ & $(1.1-4.8)$ & $(2.0-7.0)$ \\
\hline $\begin{array}{l}\text { Rural backgr. } \\
\text { (Annual) }\end{array}$ & $\begin{array}{l}0.4 \\
(0.1-1.4)\end{array}$ & & $\begin{array}{l}0.4 \\
(<0.1-1.7)\end{array}$ & & $\begin{array}{l}0.8 \\
(0.1-3.1)\end{array}$ & \\
\hline
\end{tabular}

1. Positive artefact estimated by QBQ-approach

Table 6b. Mean (min-max) relative contribution the carbon content of sugars and sugar-alcohols to the non-corrected water-soluble organic carbon (WSOC) fraction of $\mathrm{PM}_{10}(\%)$.

\begin{tabular}{llll}
\hline Site & Sugars/WSOC & $\begin{array}{l}\text { Sugar- } \\
\text { alcohols/WSOC }\end{array}$ & $\begin{array}{l}\text { Sugars and sugar- } \\
\text { alcohols/WSOC }\end{array}$ \\
\hline Urb. background (Fall) & 1.9 & 0.1 & 2.0 \\
& $(0.4-5.9)$ & $(<0.1-0.3)$ & $(0.4-6.0)$ \\
Curbside (Fall) & 2.7 & 0.7 & 3.4 \\
& $(0.9-13)$ & $(0.3-2.5)$ & $(1.2-16)$ \\
Suburban (Winter) & 0.6 & 0.1 & 0.6 \\
Suburban (Summer) & $(0.3-1.1)$ & $(<0.1-0.1)$ & $(0.3-1.2)$ \\
& 3.1 & 0.7 & 3.9 \\
& $(1.1-6.3)$ & $(0.4-1.4)$ & $(1.6-7.3)$ \\
\hline
\end{tabular}

The study of Kiss et al. (2002) indicates that polyhydroxy compounds (e.g. sugars and sugar-alcohols) are present in the WSOC fraction not isolated by the HLB-approach (Varga et al., 2000), typically accounting for $20-40 \%$ of the total WSOC fraction. Assuming that $30 \%$ of WSOC is not isolated by the HLB-approach, $2-12 \%$ of the carbon content of this non-isolated fraction could be attributed to the four sugars and three sugar alcohols analysed. Since carbohydrates take up water already at medium or low relative humidity, the relatively high growth factors observed for this fraction in hygroscopic tandem differential mobility analyser (H-TDMA) experiments (Gysel et al., 2004) could be explained by the presence of sugar and sugar-alcohol compounds. Furthermore, by increasing the water uptake of the aerosols, these components may change their light scattering properties, thus influencing the direct aerosol forcing (Ramanathan et al., 2001).

\section{Conclusions}

The present study showed that sugar and sugar-alcohols were present in ambient aerosols in a range of various environments. Daily concentrations exceeding $500 \mathrm{ng} \mathrm{m}^{-3}$ were observed for the sum of the four sugars and the three sugaralcohols quantified in $\mathrm{PM}_{10}$. The mean relative contribution of the carbon content of the sugars and sugar-alcohols to particulate $\mathrm{OC}$ in $\mathrm{PM}_{10}$, ranged from $0.6-4.7 \%$ for the sites investigated.

The sugars and sugar-alcohols were associated primarily with coarse aerosols, however, a shift towards submicron particle sizes was observed at one of the sites, which was heavily influenced by wood burning. Thus, we propose that wood burning could be an important source of both sugars and sugar-alcohols in fine aerosols.

A seasonal pattern was observed for both sugars and sugar-alcohols at the rural background site Birkenes, both reaching maximum concentrations during summer and fall. On an annual basis, approximately $80 \%$ of the sum of sugars and sugar-alcohols resided in the coarse fraction at this site. However, the fine fraction contributed significantly to 
Table 7a. Mean (min-max) relative contribution of the carbon content of sugars and sugar-alcohols to the non-corrected (OC) and the corrected $\left(\mathrm{OC}_{P}\right)$ organic carbon fraction of $\mathrm{PM}_{2.5}(\%)$.

\begin{tabular}{llllllll}
\hline Site & $\begin{array}{l}\text { Sugars/ } \\
\text { OC }\end{array}$ & $\begin{array}{l}\text { Sugars/ } \\
\mathrm{OC}_{P}\end{array}$ & $\begin{array}{l}\text { Sug. alcs./ } \\
\text { OC }\end{array}$ & $\begin{array}{l}\text { Sug. } \\
\mathrm{OC}_{P}\end{array}$ & $\begin{array}{l}\text { alcs./ } \\
\text { OC }\end{array}$ & $\begin{array}{l}\text { Sugars and sug. alcs./ } \\
\text { OC }_{P}\end{array}$ \\
\hline Urb. background & 0.2 & 0.3 & $<0.1$ & $<0.1$ & 0.2 & 0.4 \\
(Fall) & $(0.1-0.7)$ & $(0.1-1.1)$ & $\begin{array}{l}(<0.1-0.1) \\
(<0.1-0.1)\end{array}$ & $(0.1-0.8)$ & $(0.1-1.2)$ \\
Curbside & 0.1 & 0.1 & $<0.1$ & 0.1 & 0.2 & 0.2 \\
(Fall) & $(0.1-0.2)$ & $(0.1-0.4)$ & $(<0.1-0.1)$ & $(<0.1-0.1)$ & $(0.1-0.3)$ & $(0.1-0.5)$ \\
Suburban $^{1)}$ & 0.3 & 0.4 & $<0.1$ & 0.1 & 0.3 & 0.5 \\
(Winter) & $(0.1-0.6)$ & $(0.2-1.0)$ & $(<0.1-0.1)$ & $(<0.1-0.1)$ & $(0.1-0.6)$ & $(0.2-1.1)$ \\
Suburban & 0.6 & 0.9 & 0.1 & 0.1 & 0.7 & 1.0 \\
(Summer) & $(0.4-3.8)$ & $(0.3-2.6)$ & $(<0.1-0.1)$ & $(<0.1-0.2)$ & $(0.2-1.7)$ & $(0.4-2.7)$ \\
Rural backgr. & 0.2 & & $<0.1$ & & 0.2 & \\
(Annual) & $(0.1-1.0)$ & & $(0-0.2)$ & & $(0.1-1.0)$ & \\
\hline
\end{tabular}

1. Sucrose is not accounted for at this site!

Table 7b. Mean (min-max) relative contribution of the carbon content of sugars and sugar-alcohols to the water-soluble organic carbon (WSOC) fraction of $\mathrm{PM}_{2.5}(\%)$.

\begin{tabular}{llll}
\hline Site & Sugars/WSOC & $\begin{array}{l}\text { Sugar- } \\
\text { alcohols/WSOC }\end{array}$ & $\begin{array}{l}\text { Sugars and sugar- } \\
\text { alcohols/WSOC }\end{array}$ \\
\hline Urban background (Fall) & $\begin{array}{l}0.5 \\
(0.2-1.2)\end{array}$ & $<0.1$ & 0.5 \\
& $(<0.1-0.1)$ & $(0.2-1.3)$ \\
\hline
\end{tabular}

the concentration of sugars in $\mathrm{PM}_{10}$ during winter, spring and early summer. We argue that ruptured pollen may be a significant source of sugars in the fine aerosol during spring and early summer.

Edited by: Y. Rudich

\section{References}

Bauer, H., Kasper-Giebl, A., Löflund, M., Giebl, H., Hitzenberger, R., Zibuschka, F., and Puxbaum, H.: The contribution of bacteria and fungal spores to the organic carbon content of cloud water, precipitation and aerosols, Atmos. Res., 64, 109-119, 2002.

Carvalho, A., Pio, C., and Santos, C.: Water-soluble hydroxylated organic compounds in German and Finnish aerosols, Atmos. Environ., 37, 1775-1783, 2003.

Claeys, M., Graham, B., Vas, G., Wang, W., Vermeylen, R., Pashynska, V., Cafmeyer, J., Guyon, P., Andreae, M. O., Artaxo, P., and Maenhaut, W.: Formation of secondary organic aerosols through photooxidation of isoprene, Science, 303, 1173-1176, 2004.

Decesari, S., Fuzzi, S., Facchini, M.C., Mircea, M., Emblico, L., Cavalli, F., Maenhaut, W. Chi, X., Schkolnik, G., Falkovich, A., Rudich, Y., Claeys, M., Pashynska, V., Vas, G., Kourtchev, I., Vermeylen, R., Hoffer, A., Andreae, M. O., Tagliavini, E., Moretti, F., and Artaxo, P.: Characterization of the organic composition of aerosols from Rondônia, Brazil, during the LBASMOCC 2002 experiment and its representation through model compounds, Atmos. Chem. Phys., 6, 375-402, 2006, http://www.atmos-chem-phys.net/6/375/2006/.

Dye, C. and Yttri, K. E.: Determination of monosaccharide anhydrides in atmospheric aerosols by use of high-resolution mass spectrometry combined with high performance liquid chromatography, Anal. Chem., 77, 1853-1858, 2005.

Edney, E. O., Kleindienst, T. E., Jaoui, M., Lewandowski, M., Offenberg, J. H., Wang, W., and Claeys, M.: Formation of 2-methyl tetrols and 2-methylglyceric acid in secondary organic aerosol from laboratory irradiated isoprene/ $\mathrm{NO}_{\mathrm{x}} / \mathrm{SO}_{2} /$ air mixtures and their detection in ambient $\mathrm{PM}_{2.5}$ samples collected in the eastern United States, Atmos. Environ., 39, 5281-5289, 2005.

Elbert, W., Taylor, P. E., Andreae, M. O., and Pöschl, U.: Contribution of fungi to primary biogenic aerosols in the atmosphere: active discharge of spores, carbohydratres, and inorganic ions by Asco-and Basidiomycota, Atmos. Chem. Phys. Discuss., 6, 11317-11 355, 2006.

Facchini, M. C., Mircea, M., Fuzzi, S., and Charlson, R. J.: Cloud albedo enhancement by surface-active organic solutes in growing droplets, Nature, 401, 257-259, 1999.

Falkovich, A. H., Graber, E. R., Schkolnik, G., Rudich, Y., Maenhaut, W., and Artaxo, P.: Low molecular weight organic acids in aerosol particles from Rondônia, Brazil, during the biomassburning, transition and wet periods, Atmos. Chem. Phys., 5, 781797, 2005, http://www.atmos-chem-phys.net/5/781/2005/.

Fine, P. M, Cass, G., and Simoneit, B. R. T.: Chemical characterization of fine particle emissions from the fireplace combustion of woods grown in the Southern United States, Environ. Sci. Technol., 36, 1442-1451, 2002. 
Fraser, M. P. and Lakshmanan, K.: Using levoglucosan as a molecular marker for the long range transport of biomass combustion aerosols, Environ. Sci. Technol., 34, 4560-4564, 2000.

Graber, E. R. and Rudich, Y.: Atmospheric HULIS: How humiclike are they? A comprehensive and critical review, Atmos. Chem. Phys., 6, 729-753, 2006,

http://www.atmos-chem-phys.net/6/729/2006/.

Graham, G., Falkovich, A. H., Rudich, Y., Maenhaut, W., Guyon, P., and Andreae, M. O.: Local and regional contributions to the atmospheric aerosol over Tel Aviv, Israel: a case study using elemental, ionic and organic tracers, Atmos. Environ., 38, 15931604, 2004.

Graham, B., Guyon, P., Taylor, P. E., Artaxo, P., Maenhaut, W., Glovsky, M. M., Flagan, R.C., and Andreae, M. O.: Organic compounds present in the natural Amazonian aerosol: Characterization by gas chromatography-mass spectrometry, J. Geophys. Res., 108, 4766, doi:10.1029/2003JD003990, 2003.

Graham, B., Mayol-Bracero, O.L., Guyon, P., Roberts, G. C., Decesari, S. Facchini, M. C., Artaxo, P., Maenhaut, W., Köll, P., and Andreae, M. O.: Water-soluble organic compounds in biomass burning aerosols over Amazonia 1. Characterization by NMR and GC-MS, J. Geophys. Res., 107, 8047, doi:10.1029/2001JD000336, 2002.

Gysel, M., Weingartner, E., Nyeki, S., Baltensperger, U., Galambos, I., and Kiss, G.: Hygroscopic properties of water soluble matter and humic-like organics in atmospheric fine aerosol, Atmos. Chem. Phys., 4, 35-50, 2004, http://www.atmos-chem-phys.net/4/35/2004/.

Havers, N., Burba, P., Lambert, J., and Klockow, D.: Spectroscopic characterization of humic-like substances in airborne particulate matter, J. Atmos. Chem., 29, 45-54, 1998.

Hopke, P. K., Xie, Y., Raunemaa, T., Biegalski, S., Landsberger, S., Maenhaut, W., Artaxo, P., and Cohen, D.: Characterization of the gent stacked filter unit $\mathrm{PM}_{10}$ sampler, Aerosol Sci. Technol., 27, 726-735, 1997.

Ion, A. C., Vermeylen, R., Kourtchev, I., Cafmeyer, J., Chi, X., Gelencser, A., Maenhaut, W., and Claeys, M.: Polar organic compounds in rural PM2.5 aerosols from K-puszta, Hungary, during a 2003 summer field campaign: Sources and diel variations, Atmos. Chem. Phys., 5, 1805-1814, 2005, http://www.atmos-chem-phys.net/5/1805/2005/

Kamens, R., Bell, D., Dietrich, A., Perry, J., Goodman, R., Claxton, L., and Tejada, S.: Mutagenic transformations of dilute wood smoke systems in the presence of ozone and nitrogen dioxide analysis of selected high-pressure liquid chromatography fractions from wood smoke particle extracts, Environ. Sci. Technol., 19, 63-69, 1985.

Kawamura, K. and Yasui, O.: Diurnal changes in the distribution of dicarboxylic acids, ketocarboxylic acids and dicarbonyls in the urban Tokyo atmosphere, Atmos. Environ., 39, 1945-1960, 2005

Kerminen, V. M., Ojanen, C., Pakkanen, T., Hillamo, R., Aurela, M., and Merilainen, J.: Low-molecular-weight dicarboxylic acids in an urban and rural atmosphere, J. Aerosol Sci., 31, 349362,2000

Kirchstetter, T. W., Corrigan, C. E., and Novakov, T.: Laboratory and field investigation of the adsorption of gaseous organic compounds onto quartz filters, Atmos. Environ., 35, 1663-1671, 2001
Kiss, G., Varga, B., Galambos, I., and Ganszky, I.: Characterization of water-soluble organic matter isolated from atmospheric fine aerosol, J. Geophys. Res., 107, 8339, doi:10.1029/2001JD000603, 2002.

Kleefeld, S., Hoffer, A., Krivácsy, Z., and Jennings, S. G.: Importance of organic and black carbon in atmospheric aerosols at Mace Head, on the west coast of Ireland, Atmos. Environ., 36, 4479-4490, 2002.

Krivácsy, Z., Gelencser, A., Kiss, G., Meszaros, E., Molnar, A., Hoffer, A., Meszaros, T., Sarvari, Z., Temesi, D., Varga, B., Baltensperger, U., Nyeki, S., and Weingartner, E.: Study on the chemical character of water soluble organic compounds in fine atmospheric aerosol at the Jungfraujoch, J. Atmos. Chem., 39, 235-259, 2001.

Kourtchev, I., Ruuskanen, T., Maenhaut, W., Kulmala, M., and Claeys, M.: Observation of 2-methyltetrols and related photooxidation products of isoprene in boreal forest aerosols from Hyytiala, Finland, Atmos. Chem. Phys., 5, 2761-2770, 2005, http://www.atmos-chem-phys.net/5/2761/2005/.

Lewis, D. H. and Smith, D. C.: Sugar-alcohols (polyols) in fungi and green plants. I. Distribution, physiology and metabolism, New Phytol., 66, 143-184, 1967.

Mader, B. T., Yu, J. Z., Xu, J. H., Li, Q. F., Wu, W. S., Flagan, R. C., and Seinfeld, J. H.: Molecular composition of the water-soluble fraction of atmospheric carbonaceous aerosols collected during ACE-Asia, J. Geophys. Res., 109, D06206, doi:10.1029/2003JD004105, 2004.

Matthias-Maser, S.: Primary biological aerosol particles: Their significance, sources, sampling methods and size distribution in the atmosphere, in: Atmospheric particles, edited by: Harrison, R. M. and van Grieken, R., John Wiley \& Sons, Chichester, 349368, 1998.

Mayol-Bracero, O. L., Guyon, P., Graham, B., Roberts, G., Andreae, M. O., Decesari, S., Facchini, M. C., Fuzzi, S., and Artaxo, P.: Water-soluble organic compounds in biomass burning aerosols over Amazonia - 2. Apportionment of the chemical composition and importance of the polyacidic fraction, J. Geophys. Res., 107, 8091, doi:10.1029/2001JD003249, 2002.

McDow, S. R. and Huntzicker, J. J.: Vapor adsorption artifact in the sampling of organic aerosol: face velocity effects, Atmos. Environ., 24A, 2563-2571, 1990.

Medeiros, P. M., Conte, M. H., Weber, J. C., and Simoneit, B R. T.: Sugars as source indicators of biogenic organic carbon in aerosols collected above the Howland Experimental Forest, Maine, Atmos. Environ., 40, 1694-1705, 2006.

Medeiros, P. M. and Simoneit, B. R. T.: Analysis of sugars in environmental samples by gas chromatography-mass spectrometry, J. Chromatogr., A, 1141, 271-278, 2007.

Nolte, C. G., Schauer, J. J., Cass, G. R., and Simoneit, B. R. T.: Highly polar organic compounds present in wood smoke and in the ambient atmosphere, Environ. Sci. Technol., 35, 1912-1919, 2001.

Novakov, T. and Penner, J. E.: Large contribution of organic aerosols to cloud condensation nuclei concentrations, Nature, 365, 823-826, 1993.

Pacini, E.: From anther and pollen ripening to pollen presentation, Plant Syst. Evol., 222, 19-43, 2000.

Pashynska, V., Vermeylen, R., Vas, G., Maenhaut, W., and Claeys, M.: Development of a gas chromatographic/ion trap mass spec- 
trometric method for the determination of levoglucosan and saccharidic compounds in atmospheric aerosols. Application to urban aerosols, J. Mass Spectrom., 37, 1249-1257, 2002.

Ramanathan, V., Crutzen, P. J., Kiehl, J. T., and Rosenfeld, D.: Aerosols, climate and the hydrological cycle, Science, 294, 2119-2124, 2001.

Romero, F. and Oehme, M.: Organosulfates - A new component of humic-like substances in atmospheric aerosols?, J. Atmos. Chem., 52, 283-294, 2005.

Sanders, E. B., Goldsmith, A. I., and Seeman, J. I.: A model that distinguishes the pyrolysis of D-glucose, D-fructose, and sucrose from that of cellulose. Application to the understanding of cigarette smoke formation, J. Anal. Appl. Pyrolysis, 66, 29-50, 2002.

Saxena, P. and Hildemann, L. M.: Water-soluble organics in atmospheric particles: A critical review of the literature and application of thermodynamics to identify candidate compounds, J. Atmos. Chem., 24, 57-109, 1996.

Schauer, J. J., Kleeman, M. J, Cass, G. R., and Simoneit, B. R. T.: Measurement of emissions from air pollution sources. 3. $\mathrm{C}_{1}-\mathrm{C}_{29}$ organic compounds from fireplace combustion of wood, Environ. Sci. Technol., 35, 1716-1728, 2001.

Schkolnik, G., Falkovich, A. H., Rudich, Y., Maenhaut, W., and Artaxo, P.: A new method for the determination of levoglucosan, methyl-erythritol and related compounds and its application for rainwater and smoke samples, Environ. Sci. Technol., 39, 2744 $2752,2005$.

Schkolnik, G. and Rudich, Y.: Detection and quantification of levoglucosan in atmospheric aerosols - review, Anal. Bioanal. Chem., 385, 26-33 doi:10.1007/s00216-005-0168-5 2006.

Simoneit, B. R. T.: Biomass burning - a review of organic tracers for smoke from incomplete combustion, Appl. Geochem., 17, 129-162, 2002.

Simoneit, B. R. T., Elias, V. O., Kobayashi, M., Kawamura, K., Rushdi, A. I., Medeiros, P. M., Rogge, W. F., and Didyk, B. M.: Sugars - Dominant water-soluble organic compounds in soils and characterization as tracers in atmospheric particulate matter, Environ. Sci. Technol., 38, 5939-5949, 2004.

Stohl, A., Berg, T., Burkhart, J. F., Fjæraa, A. M., Forster, C., Herber, A., Hov, Ø., Lunder, C., McMillan, W. W., Oltmans, S., Shiobara, M., Simpson, D., Solberg, S., Stebel, K., Ström, J., Tørseth, K., Treffeisen, R., Virkkunen, K., and Yttri, K. E.: Arctic smoke - record high air pollution levels in the European Arctic due to agricultural fires in Eastern Europe. Atmos. Chem. Phys. 7, 511-534, 2007.
Surratt, J. D., Kroll, J. H., Kleindienst, T. E., Edney, E. O., Claeys, M., Sorooshian, A., Ng, N. L., Offenberg, J. H., Lewandowski, M., Jaoui, M., Flagan, R. C., and Seinfeld, J. H.: Evidence for organosulfates in secondary organic aerosol. Environ. Sci. Technol., 41, 517-527, 2007.

Surratt, J. D., Murphy, S. M., Kroll, J. H., Ng, N. L., Hildebrandt, L., Sorooshian, A., Szmigielski, R., Vermeylen, R., Maenhaut, W., Claeys, M., Flagan, R. C., and Seinfeld, J. H.: Chemical composition of secondary organic aerosol formed from the photooxidation of isoprene. J. Phys. Chem. A., 6, 110, 9665-9690, 2006.

Taylor, P. E., Flagan, R. C., Miguel, A. G., Valenta, R., and Glovsky, M. M.: Birch pollen rupture and the release of aerosols of respirable allergens, Clin. Exp. Allergy, 34, 1591-1596, 2004.

Taylor, P. E., Flagan, R. C., Valenta, R., and Glovsky, M. M.: Release of allergens as respirable aerosols: A link between grass pollen and asthma, J. Allergy Clin. Immun.. 109, 51-56, 2002.

Tesfaigzi, Y., Singh, S. P., Foster, J. E., Kubatko, J., Barr, E. B., Fine, P. M., McDonald, J. D., Hahn, F. F., and Mauderly, J. L.: Health effects of subchronic exposure to low levels of wood smoke in rats, Toxicol. Sci., 65, 115-125, 2002.

Varga, B., Kiss, G., Ganszky, I., Gelencser, A., and Krivacsy, $\mathrm{Z}$.: Isolation of water-soluble organic matter from atmospheric aerosol, Talanta, 55, 561-572, 2001.

Yttri, K. E., Dye, C., Slørdal, L. H., and Braathen, O.-A.: Quantification of monosaccharide anhydrides by negative electrospray HPLC/HRMS-TOF - Application to aerosol samples from an urban and a suburban site influenced by small scale wood burning, J. Air Waste Ma., 55, 1169-1177, 2005.

Zappoli, S., Andracchio, A., Fuzzi, S., Facchini, M. C., Gelencser, A., Kiss, G., Krivacsy, Z., Molnar, A., Meszaros, E., Hansson, H. C., Rosman, K., and Zebuhr, Y.: Inorganic, organic and macromolecular components of fine aerosol in different areas of Europe in relation to their water solubility, Atmos. Environ., 33, 27332743, 1999.

Zdráhal, Z., Oliveira, J., Vermeylen, R., Claeys, M., and Maenhaut, W.: Improved method for quantifying levoglucosan and related monosaccharide anhydrides in atmospheric aerosols and application to samples from urban and tropical locations, Environ. Sci. Technol., 36, 747-757, 2002. 